\title{
Editorial
}

\section{Unquoted Companies and Inheritance Tax}

\author{
Barry Bracewell-Milnes, Banstead
}

Unemployment is a significant problem throughout the European Union; and much of the economic responsibility for dealing with it lies with the unquoted sector of business, comprising unquoted companies and unincorporated firms. Most of the jobs created in recent years have been in the unquoted sector, while quoted companies and state-sector concerns have been shedding labour. For this and other reasons the unquoted sector is important to the development of the European economy and may even be the chief influence on its future prosperity.

Principal characteristics of long-term family companies are the long time-horizons of their owner-managers, their immunity to short-term fluctuations in the prices of their shares and the importance of transmitting a thriving business to the next generation às a dominant motive affecting behaviour. These companies also often invest heavily in employee loyalty, the returns from which can be substantial in the long term. All this means that inheritance tax and other forms of charge on transfers mortis causa or inter vivos, irrespective of whether they are levied on the transferor or the transferee, can be a heavy burden for long-term family businesses and may make it impossible for them to survive as such.

Directorate-General XXIII of the European Commission is therefore to be congratulated on addressing this subject in the round and at length in two documents which have not so far received the attention they deserve. The Communication from the Commission on the Transfer of Businesses: Actions in Favour of SMEs (94/C 204/01) was published in the Official Journal of the European Communities on 23 July 1994. The Communication on the Commission recommendation of 7 December 1994 on the transfer of small and medium-sized enterprises (C(94)3312) was published on 31 December 1994 (with input from the Member States). Although both documents refer to small and medium-sized enterprises, their subject matter and argumentation are equally relevant to larger family companies, which can be larger than many quoted companies.

The object of the Communication of 23 July was to stimulate a debate about the problems relating to the transfer of businesses. Highlights of its analysis were:

- (Transfer of ownership) 'is a problem particularly for small and medium sized businesses, which are the backbone of the Community's economy.'

- 'The Commission and the Member States are therefore placing great hopes on SMEs to lift the European economy out of crisis and put it back on the road to recovery.'

- 'A large portion of the profits generated by the transferred company are used by the heirs to pay inheritance tax and thus cannot be ploughed back into the company. In the meantime, a rival enterprise not affected by transfer-of-ownership problems continues to invest and thus gains a competitive edge. It should also be noted that this tax system puts European enterprise at a disadvantage in relation to the rest of the world.'

- (If inheritance tax on SMEs were reduced) 'this possible loss of revenue would in any case be largely offset by a reduction in the number of enterprises liquidated and thus a decrease in concomitant losses in terms of economic activity and employment, and by an increase in revenue in the form of taxes on businesses, VAT and social contributions paid by surviving enterprises. It is even possible that profits will outstrip the losses caused by changes to the business inheritance tax laws, as the economic activity of the surviving enterprise will have numerous indirect beneficial effects on suppliers, subcontractors, clients and employees who in turn will pay income tax, VAT and social contributions.'

The document of 7 December goes on from further analysis to recommendations:

- 'Company law and tax legislation also have a decisive influence on the success or failure of this process' (the transfer of a business from one generation to another).

- 'Taxing a small or medium-sized enterprise at current rates . . can lead to its disappearance and resulting job losses.' 
- Member States are invited to ... reduce the taxes on assets exclusively used for the business in the case of transfer by gift or succession, including inheritance tax, gift tax and registration fees, provided the business is kept as a going concern for a reasonable period.'

- 'The Commission requests the Member States to reduce the burden of taxation on the transfer of businesses effected in the form of inter vivos gifts, or transmission on death (inheritance tax, gift tax, registration fees), as in the British system, with the aim of ensuring that their taxation policy is better adapted to ensuring the survival of businesses.' Inheritance tax, whether on business property or otherwise, has not so far been the subject of Commission initiatives on harmonisation. Sooner or later, this may change; if it does, it is important that harmonisation should be downwards rather than upwards. In general, inheritance tax is increasingly regarded as an obsolete tax, lacking intellectual and political support and having no rational function in a modern tax system. As it applies to business property in particular, there is no serious argument for levying inheritance tax on business property at all. United Kingdom experience indicates that a legally watertight distinction can be drawn for purposes of inheritance tax between business property and other assets and that several years' experience of business property relief at 100 per cent has provided no evidence of taxpayers' abusing the system. United Kingdom success in this policy area may owe something to its strong representative bodies in a constituency that is naturally difficult to organise. United Kingdom experience also shows that tax reduction in this area is very cheap even in the conventional sense (in other words, without allowing for the 'second-round' and 'incentive' effects acknowledged by the European Commission to be important when an identifiable tax distortion is being removed). At the time of writing this editorial, the cost of extending 100 per cent business property relief in the United Kingdom to all assets at present eligible for a lower rate of relief is now put at $£ 5$ million or less by the tax authorities themselves, $£ 5$ million being the lowest significant figure now used in the government's financial accounts.

At the time of writing, much has been achieved in the United Kingdom, although not yet everything that is economically desirable. Less has been achieved elsewhere in the European Union. As is implied by what the European Commission has said, the implied competitive advantage of the United Kingdom over the rest of the European Union is less important than the competitive disadvantage of the whole European Union relatively to the rest of the world. The economic strength of the unquoted sector is devolution and decentralisation; the unquoted sector cannot therefore easily provide representative and lobbying muscle proportional to the strength of its arguments. If the unquoted sector's arguments are not promoted, like those of other interested parties, they will be ignored. It is therefore in the interest of long-term unquoted companies, partnerships and sole proprietorships and their advisors and representative bodies throughout the European Union to use the broad hint provided by the European Commission and to press for the abolition of inheritance tax on all forms of business property. 